\title{
Comparison of Bone Mineral Density of Dominant and Non-dominant Forearm of Badminton Players
}

\author{
Mustafa Şakir AKGÜL ${ }^{1}$, Arzu ALTUNEL ${ }^{2}$, Veli Volkan GÜRSES ${ }^{3}$ Bilgehan \\ BAYDİL 4
}

1-Mustafa Şakir Akgül, Kastamonu University, School of Physical Education and Sports, Kastamonu, Turkey.

2-Arzu Altunel, Kastamonu University, School of Physical Education and Sports, Kastamonu, Turkey.

3-Veli Volkan Gürses, Kastamonu University, School of Physical Education and Sports, Kastamonu, Turkey.

4-Bilgehan Baydil, Kastamonu University, School of Physical Education and Sports, Kastamonu, Turkey.

Address Correspondence to MŞ.Akgül, e-mail: msakgul@kastamonu.edu.tr

\begin{abstract}
Research related to arm bone density of badminton players focused mainly on humerus, how much forearm exposed to physical load is affected by this stress has been studies less. Thus, the aim of this study was to investigate mineral density of dominant and non-dominant forearm bone mineral density of badminton players who have been regularly playing badminton for 10 years. 12 male badminton players whose dominant arms were the same voluntarily participated in this study. Bone Mineral Density (BMD) of the players was evaluated with Dual X Ray Absorptiometry (DEXA). Data was evaluated with SPSS 23. Controlled research method was used to estimate BMD of the players. Differences between dominant and non-dominant arms were assessed with a non-parametric test, Wilcoxon Signed Rank Test. P value was set at $\mathrm{p}<0.05$. Significant difference was found between BMD of dominant right ultra-distal part and BMD of non-dominant left ultra-distal part (z:-2,94, sig:0,00) and between BMD of dominant right proximal part and BMD of non-dominant left proximal part (z:-2,09, sig:0,03). There was no significant difference between dominant proximal 1/3 part and non-dominant proximal 1/3 part (z:1,85, sig:0,06). As a result, long-term badminton training has positive effects on BMD.
\end{abstract}

Keywords: Badminton, bone mineral density, forearm.

\section{INTRODUCTION}

Osteoporosis is a metabolic bone illness characterized by decrease in BMD and bone strength, bone fragility and increase in fracture risk, deformation in bone tissue. Osteoporosis is a big threat for public health $(2,8)$

Maximizing BMD till the age of 30 is of great importance for hindering or postponing osteoporosis. Therefore, protective measures should be taken during childhood or youth and increasing BMD should be at the highest level if possible (4). Although genetic factors seem to affect bone mass, exercise, hormonal situation and nutrition can change bone structure (15). Changes in exercise, nutrition and hormonal changes with the aging shape the skeletal structure. BMD increases acutely till the ages of 15-20 and this increase continue slowly till the age of 30 (5). $60 \%$ of the bone development appears in adolescence, the earliest age of reaching peak bone mass (PBM) is 17-18 and 35 at the latest (16). PBM acquired during young adulthood is under genetic control and is an important indicator of BMD of farther ages (12).

Physical activity help bones tolerate high level of stresses and it is effective during growth period (16). Bone is an active tissue which develops when exposed to load and weaken when the load does not appear. Bone tissue changes and adjust to resist against the load by strain, flexion and compression (17). A study indicates that high frequency of physical activity during early ages is important to hinder osteoporosis (14). Most studies state that regular physical activity positively affects bone health $(7,10)$. Numerous studies have investigated the effects of a specific sport on BMD $(19,3)$. However, there are almost no study investigating especially effects of long-term interaction with badminton on BMD of forearm.

Although there are many methods evaluating bone tissue, Dual Energy X-Ray Absorptiometry 
(DEXA) is a method to evaluate BMD and bone mineral content (13). DEXA is accepted as golden standard due to its value, usage limitedness and qualified technical personnel. It provides certain results in bone mineral content measurements (16).

Due to aforementioned reasons, the aim of this study was to investigate BMD in dominant and nondominant arms of badminton players. Determining BMD of dominant and non-dominant forearm of athletes playing badminton for a long time is thought to play an important role in exploring the effect of badminton on BMD.

\section{MATERIAL AND METHOD}

Twelve badminton players whose dominant hands were the same voluntarily participated in this study. Players having at least ten years of badminton experience, with no orthopedic health problem and with acceptable BMD according to age and gender were included in this study. Each participant was informed about the content of the study and their consent was obtained. The body height and body weight were measured after taking the position in anatomical posture in such a way that heels adjacent, holding breath, head on the frontal plane, overhead plate touching the vertex point and the measurements were recorded in "cm" and "kg". The body height of the subjects was measured with stadiometer with a precision of \pm 1 $\mathrm{mm}$ (Seca 213). The body weights were measured with an electronic scale with a precision of $\pm 100 \mathrm{~g}$ (Seca 760). Physical characteristics of the participants are presented in Table 1.

\begin{tabular}{ll}
\hline Table 1. Physical characteristics of badminton players \\
\hline Variables (n=12) & Mean \pm SD \\
\hline Age (years) & $20.33 \pm 2.54$ \\
Height $(\mathrm{cm})$ & $178.00 \pm 6.19$ \\
Body Weight $(\mathrm{kg})$ & $78.50 \pm 5.36$ \\
\hline
\end{tabular}

\section{Bone mineral density measurement}

BMD of the dominant arm (forearm) with which players use the racket and non-dominant arm was measured with the method of Dual X Ray Absorptiometry (DEXA). Forearm bones were radioed with Hologic QDR-4500 A and Hologic 4500 C. Specific areas such as radius and ulna were chosen with the help of software of the system. Analysis was carries out on ultra-distal and 1/3 proximal bone areas and BMD of three different areas were calculated as $\mathrm{g} / \mathrm{cm} 2$.

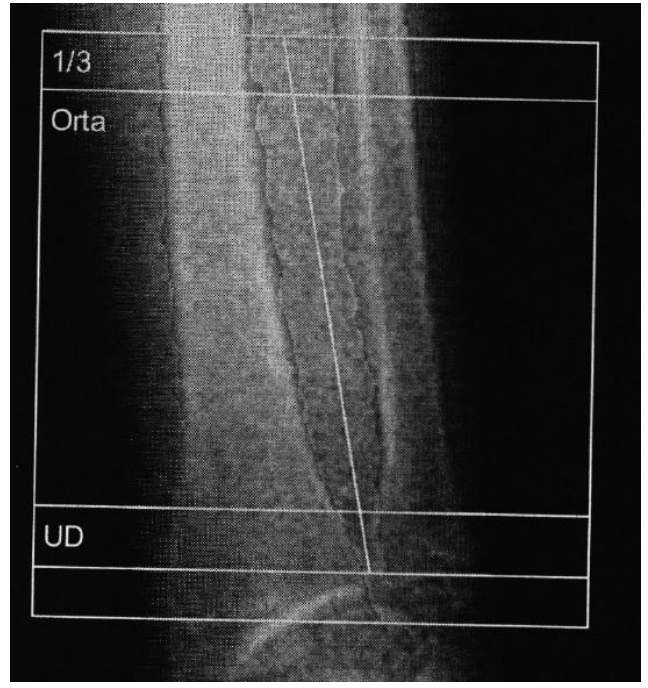

Figure 1. Reference areas (for dominat and non dominant forearm).

Data were evaluated with SPSS 23. Controlled research method was used to estimate BMD of the players. Therefore, Wilcoxon Signed Rank Test, a non-parametric test, was used to determine differences in BMD of the right and left forearms of the badminton players. $P$ value was set at $\mathrm{p}<0.05$.

\section{RESULTS}

Significant difference was found in BMD between dominant right ultra-distal area and nondominant left ultra-distal area (z:-2,94, sig:0,00) and between dominant right middle proximal area and non-dominant left middle proximal area (z:-2,09, sig:0,03). No significant difference was found in BMD between dominant proximal $1 / 3$ area and nondominant proximal 1/3 area (z:1,85, sig:0,06). Results are given in Table 2.

Table 2. BMD of dominant and non-dominant forearm reference areas

\begin{tabular}{|c|c|c|c|}
\hline Variables $(\mathrm{n}=12) \quad\left(\mathrm{g} / \mathrm{cm}^{2}\right)$ & Mean \pm SD & $\mathrm{Z}$ & sig \\
\hline Right Ultra BMD & $0.58 \pm 0.09$ & \multirow{2}{*}{-2.94} & \multirow{2}{*}{$0,00^{*}$} \\
\hline Left Ultra BMD & $0.53 \pm 0.89$ & & \\
\hline Right Middle BMD & $0.86 \pm 0.09$ & \multirow{2}{*}{-2.09} & \multirow{2}{*}{$0,03^{*}$} \\
\hline Left Middle BMD & $0.82 \pm 0.09$ & & \\
\hline Right $1 / 3$ & $1.10 \pm 0.09$ & \multirow{2}{*}{-1.85} & \multirow{2}{*}{0,06} \\
\hline Left $1 / 3$ & $1.07 \pm 0.10$ & & \\
\hline
\end{tabular}

It was determined that BMD was really high in dominant forearms of the badminton players, especially areas which are actively used during badminton play compared to non-dominant forearm. In view of these findings, long-term badminton exercises can be said to be positively effective on BMD. 


\section{DISCUSSION and CONCLUSION}

The main finding of this study was that badminton players with long-term badminton experience have a higher BMD in dominant forearm than non-dominant forearm. Another important finding is that dominant forearm ultra-distal area and middle proximal area have a higher BMD values than proximal $1 / 3$ area which is less effective while playing badminton.

It is suggested that BMD increases with increase in exercise and fitness level $(1,6)$. A decrease in exercise level is stated to lead to an increase osteoporotic fractures. Researchers stating a negative significant relationship between osteoporotic fractures and exercise highlighted that individuals with a more active life have more BMD (10).

A study which compared BMD of badminton and ice hockey players stated that badminton players had more BMD than ice hockey players. Given that badminton players use forearm actively during the game, it can be concluded that badminton players have more BMD than ice hockey players (4). Another study compared BMD of long distance runners, tennis players and sedentary individuals with DEXA and found out that tennis players had significantly higher BMD values than other groups (18). It can be said that forearms of the tennis players are exposed to high amount of stress as that of badminton players.

Results of different measurement applied to different bone areas of upper body suggest that dominant arm have 20\% higher BMD than nondominant forearm while the extend of difference is $5 \%$ in sedentary individuals (11). This finding supports our results.

Previous studies focused mainly on humerus as a target area for bone characteristics of badminton players, limited study investigated how much forearm is affected by this stress exposed to high level of physical stress. Our study investigated only forearm area (radius and ulna) and compared BMD levels in dominant and non-dominant arms.

A similar study investigated BMD levels of humerus and ulna bones of both arms in women playing squash. This study presented positive correlation between BMD of dominant humerus and training years $(r=0.63-0.69)$ (9). This finding is similar to ours.
In conclusion, it is deduced that BMD of dominant forearm is significantly higher than nondominant forearm in badminton players with a long-term experience. It can be suggested that the same study should be applied to a broader experimental group.

\section{REFERENCES}

1. Alfredson $H$, Nordstrom $P$, Lorentzon R. Total and regional bone mass in female soccer players. Calcif Tissue Int, 1996; 59(6):439-442.

2. Alkan BM, Fidan F, Tosun A, Ardıçoğlu Ö. Fiziksel tıp ve rehabilitasyon polikliniğimize başvuran hastalarda osteoporoz insidans1. Türk Osteoporoz Dergisi, 2011; 17(1):1013.

3. Bozkurt İ. Effects of exercises on bone mineral densty of proximal femour region among athletes of different branches. International Journal of the Physical Sciences, 2010;5(17): 2705-2714.

4. Carrie Fassler AL, Bonjour JP. Osteoporosis as a pediatric problem. Pediatric Clinics of North America, 1995;42(4):811824.

5. Cinemre A, Turnagöl H, Okut G. Voleybolcu çocukların kemik yapılarının değerlendirilmesi. Gazi Beden Eğitimi ve spor bilimleri dergisi. 2011; 16(3):49-58.

6. Courteix D, Lespessailles E, Peres SL. Effect of physical training on bone mineral density in prepubertal girls: a comparative study between impactloading and non-impactloading sports. Osteoporos Int,1998;8(2):152-158.

7. Dana LC, Amy LM, Debra B, Gunnar PB. Weight - bearing exercise and markers of bone turnover in female athletes. J Appl Physiol, 2001; 90(2): 565-570.

8. Gül O, Atik OS, Erdoğan D, Göktaş G. Is bone microstructure different between osteopenic and osteoporotic patients with femoral neck fracture?. Eklem Hastalik Cerrahisi, 2012; 23(1):15-19.

9. Haapasalo $H$, Kannus $\mathrm{P}$, Sievanen $\mathrm{H}$, Heinonen A, Oja P, Vuori I. Long term unilateral loading and bone mineral density and content in female squash players. Calcif Tissue Int, 1994;54(4):249-255.

10. Kohrt WM, Bloomfield SA, Little KD, Nelson ME, Yingling VR. American College of Sports Medicine position stand: Physical activity and bone health. Medicine Science in Sports and Exercise, 2004; 36(11):1985-1996.

11. Kontulainen S, Kannus $\mathrm{P}$, Haapasalo $\mathrm{H}$, Heinonen A, Sievanen H, Oja P, Vuori I. Changes in bone mineral content with decreased training in competitive young adult tennis players and controls: a prospective 4-yr follow-up. Med Sci Sports Exerc, 1999;31(5):646-652.

12. Lehtonen-Veroma M, Möttönen T, Nuotio I, Heinonen OJ, Viikari J. Influence of physical activity on ultrasound and dual-energy x-ray absorptiometry bone measurements in peripubertal girls: a cross-sectional study. Calcif Tissue Int, 2000; 66(4): 248-254. 
13. Mackelvie KJ, McKay HA, Khan KM, Crocker RPE. A school exercise intervention augments bone mineral accrual in early pubertal girls. J Pediatr, 2001; 139(4): 501-508.

14. Nilsson M, Ohlsson C, Eriksson AL, Frandin K, Karlsson M, Ljunggren Ö, Mellström D, Lorentzon M. Competitive physical activity early in life is associated with bone mineral density in elderly swedish men. Osteoporos Int, 2008;19(11):1557-1566

15. Nordstorn P, Lorentzon R. Influence of heredity and enviroment on bone mineral density in adolescent boys: a parent-offspring study. Osteoporos Int, 1999; 10(4):271-277
16. O Brien M. Exercise and Osteoporosis. Ir J Med Sci, 2001;170(1):58-62.

17. Tüzün F. Osteoporoza genel bakış. Kemik ve eklem dekadında osteoporoz ve kemik kalitesi. 2nd ed. Nadir Kitap, 2003:37-45.

18. Yabancı N, Pekcan G. Adolesanlarda beslenme durumu ile fiziksel aktivite düzeyinin vücut bileşimi ve kemik mineral yoğunluğu üzerine etkisi. Aile ve Toplum, 2010;11(6):9-20.

19. Ziylan T, Özdemir M, Taştekin G, Civan A. 17- 20 yaş grubundaki güreşçilerde ve sedanterlerdeki iskelet osteoblastik aktivite dağılımlarının karşılaştırılması. Uluslararası İnsan Bilimleri Dergisi, 2010;7(1):114-123. 